\title{
Changes in diversity of protected scree and herb-rich beech forest ecosystems over 55 years
}

\author{
Vojtěch Hájek ${ }^{1}$, Zdeněk Vacek ${ }^{1}$ *, Stanislav Vacek ${ }^{1}$, Lukáš Bílek ${ }^{1}$, \\ Romana Prausová ${ }^{2}$, Rostislav Linda ${ }^{1}$, Daniel Bulušek ${ }^{1}$, Ivo Králíček ${ }^{2}$ \\ ${ }^{1}$ Czech University of Life Sciences Prague, Faculty of Forestry and Wood Sciences, Department of Silviculture, \\ Kamýcká 129, CZ - 16521 Prague, Czech Republic \\ ${ }^{2}$ University of Hradec Králové, Faculty of Science, Rokitanského 62, CZ - 50003 Hradec Králové, Czech Republic
}

\begin{abstract}
Species composition along with spatial and age structure are the main attributes of forest ecosystems. The diversity of scree forests and herb-rich beech forests was analyzed in the Broumovsko Protected Landscape Area, the Czech Republic. The paper objective was to evaluate forest structure and dynamics of species diversity of tree layer, natural regeneration and herb layer in the period 1961-2016. Scree forests were structurally, and species very rich forest stands, in herb-rich beech forests the stands were of medium richness. Studied stands managed by small-scale methods, in the past especially by coppicing and later by shelterwood and selection felling, have maintained high species biodiversity during the 55 years of observation. Substantially higher biodiversity was found out in scree forests compared to herb-rich beech forests. Based on the comparison of predominantly coppiced forest stand and stand of generative origin at sites of scree forests, coppice have maintained higher biodiversity than high forests. Species richness increased during the observation period, but species evenness had mostly decreasing tendency. Species heterogeneity in coppiced scree forests increased in tree layer and natural regeneration, but it decreased in herb layer; inverse dynamics was observed in the high forests. Changes in biodiversity dynamics were remarkable for coppice, while high forests showed relatively high level of stability. During study period herb population of light-demanding species and species characteristic for broadleaved forests decreased, while an increase in shade tolerant, moisturedemanding and nutrient-demanding species, especially nitrophilous species was confirmed. Moreover, occurrence of thermophilic plants increased, respectively cold-tolerant plant population decreased in relation to climate change.
\end{abstract}

Key words: biodiversity; forest dynamics; stand structure; phytosociology; Natura 2000

Editor: Bohdan Konôpka

\section{Introduction}

Conservation of biological diversity is a crucial goal for sustainable management in forests (Piussi \& Farrell 2000; Specker 2003; Machar et al. 2017). This is consistent with the present trend of forest management in Europe supporting higher biological diversity by the increased use of natural regeneration and creation of a higher proportion of mixed forests (Matuszkiewicz et al. 2013; Slanař et al. 2017). According to Lindenmayer (2000) the species composition of forest stand belongs among the most important elements of forest ecosystem sustainability and productivity. Species composition along with spatial and age structure are the main attributes of forest stand, influencing the ecosystem function and are mutually related with each other (Crow et al. 2002; Bulušek et al. 2016). The species composition of forest stands influences both the forest biotope by providing different cover and the microsite conditions and nutrient cycle in a forest ecosystem (Carvalho 2011; Vacek et al. 2015a, 2017b).

The tree species composition of forest stands is affected by many factors and requirements of the particular tree species. These mechanisms may have a direct influence on self-regulatory changes in the species composition and a mutual interaction in forest stands (Wilson 2011; Vacek 2014b). Among the most important factors are e.g. requirements for nutrients and light, growth or flowering phenology, long-term history of plant community and the type of forest management (Lindenmayer et al. 2000; Silvertown 2004; Kneewshaw \& Prévost 2007; Paal et al. 2011; Lhotka 2013). Particularly silvicultural practices in the past often influenced the species 
composition of a given forest stand (Battles et al. 2001; Sitzia et al. 2012; Vacek et al. 2017a). Fluctuations in the natural environment belong to other important factors, mainly specific pressure of pests (Ammer 1996), air pollution load (Král et al. 2017) and extreme climate events (Serra-Diaz et al. 2012). In recent years, biodiversity and structure of forest ecosystems is strongly affected by ongoing climatic change (Čermák et al. 2018; Vacek et al. 2019a). Global warming, long-term droughts, frequent windstorms and fires and secondary fungal pathogens, insects (especially bark beetle) and other pests have caused distinct changes in species diversity and its distributions (Iverson \& Prasad 2001; Morin et al. 2018). On the other site, forest biodiversity may mitigate climate change impacts (Hisano et al. 2018). In general, forest tree species have relatively low colonization capacity and therefore they have lower competitiveness compared to the species with wide ecological amplitude (Wulf 2003; Matuszkiewicz et al. 2013).

Tree species composition of near-natural forests can be considered as a certain expression of regeneration processes, which are highly stochastic phenomena, and so species abundance and representation may fluctuate substantially (Vacek et al. 2014a; Remeš et al. 2015; Bošela et al. 2016). Natural regeneration and subsequent interspecific interactions at this juvenile stage are influenced mainly by favourable microsite conditions in which seeds can survive, germinate and produce seedlings, and by seed availability (Snyder \& Chesson 2004; Vacek et al. 2015a). According to Paluch \& Jastrzębski (2013) an increase in the representation of one species in relation to another species is one of the factors increasing its reproduction chances. On the other hand, factors such as pathogens (Paluch \& Stępniewska 2012), vegetation cover (Beckage et al. 2005), distance between parent trees (Packer \& Clay 2003), light availability (Kunstler et al. 2005), soil moisture (Arrieta \& Suarez 2005), herbivores (Vera 2000) or other animals feeding on seeds (Lucas-Borja et al. 2012) can strongly influence regeneration success of particular tree species. So especially food-attractive broadleaved tree species and silver fir (Abies alba Mill.) are often eliminated from forest stands while considerably lower food attractiveness is evident in Norway spruce (Picea abies [L.] Karst.) - (Motta 2003; Vacek et al. 2015b, Mattila \& Kjellander 2017, Meier et al. 2017).

Studied herb-rich beech forests and scree forests in nature protection area (Natura 2000) Kozínek have maintained a high degree of forest stand naturalness and therefore a research on their diversity was launched in 1961. Long-term research plots are the most valuable objects for monitoring changes in forest ecosystems (Bakker et al. 1996). Currently the importance of these researches is confirmed by increasing number of publications dealing with long-term dynamics of forests (Hédl et al. 2017; Heinrichs \& Schmidt 2017).
The objective of the present paper was to determine changes in species diversity of tree layer, tree natural regeneration and herb layer of beech forests ecosystems from 1961 to 2016 in protected area with emphasis on structural and overall diversity of tree layer in 2016. Basic questions were: 1) How varied the biodiversity in coppice, coppice with standards (combined forest) and high forest? 2) What species and structural changes of forest stands occurred over the past 55 years in Kozínek? 3) Did distinct changes of species diversity appear in herb layer of scree forest and herb-rich beech forests? 4) Which factors caused changes in diversity of vegetation?

\section{Material and methods}

\subsection{Study site}

The research was conducted on five permanent research plots (PRP) situated in the locality Kozínek (Fig. 1, Table 1) - a protected locality in the Natura 2000 network. It was established on the area of 84.08 ha in 2004 as Special Area of Conservation (SAC) and Special Protection Area (SPA) - (AOPK 2004). The Kozínek SAC (CZ 0520507) is important for abundant occurrence of the priority biotope of scree forests (L4) along with biotopes of rock outcrops (S1.1) and also for its vast area of herb-rich beech forests (L5.1). By the representation of units L4 and S1.1 it is the most important locality in southern part of the Broumovsko Protected Landscape Area (PLA). Altitude of the locality above sea level is $378-504 \mathrm{~m}$. The slopes with many rock outcrops of the valley are deeply cut into marlstone tablelands. The bedrock is mostlybuilt of cretaceous sediments, of middle and lower Turonian or upper Cenomanian, while fluvial and fluvial-deluvial quaternary sediments are also represented (Vejlupek 1986, 1990). Prevailing soil types are Pararendzinas, Cambisols and Rankers (Mikeska et al. 2000). Climatically, according to the Hronov meteorological station (378 m a.s.l.) the Kozínek locality belongs to a moderately warm region (MT7 region; Quitt 1971) with average annual temperature of $7.2^{\circ} \mathrm{C}$ and annual precipitation amount of $742 \mathrm{~mm}$ (Vesecký 1961; Tolasz et al. 2007). In relation to climatic change, temperature increased by $1.8^{\circ} \mathrm{C}$ in period 1963-2017, while no changes were observed in precipitation regime.

Scree forests are composed of the plant associations Aceri-Carpinetum, Mercuriali-Fraxinetum and also Lunario-Aceretum to a lesser extent; herb-rich beech forests consist of the associations Aceri-Fagetum, Asperulo-Fagetum and Dentarioenneaphylli-Fagetum, and also of the association Tiliocordatae-Fagetum, which is a transition between beech forests and scree forests (Faltysová et al. 2002). Stand on PRP 2 and 3 was a high forest, coppice with standards (combined forest) were presented on PRP 1 and 4 (8\% of trees) and coppice was characterized on PRP 5. 


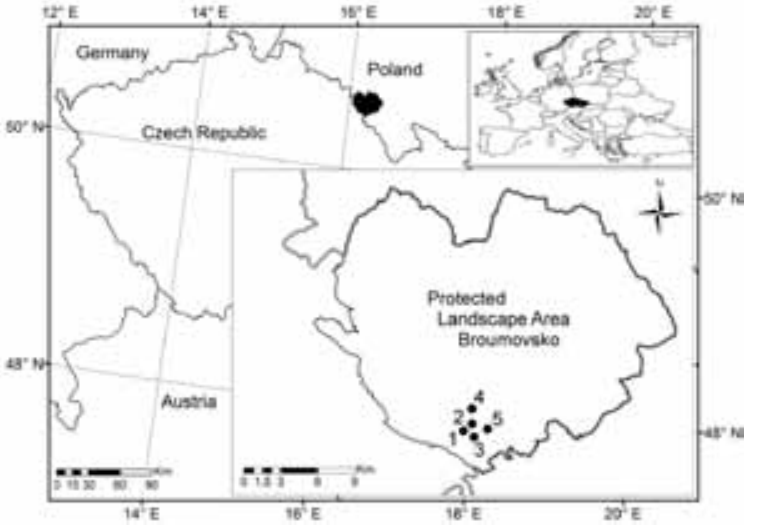

Fig. 1. Localization of permanent research plots $1-5$ at Kozínek Special Area of Conservation.
3 - trees reaching a heights $>1 / 2$ the height of the main level trees and $<$ lower $1 / 3$ of the length of their crown, $4-$ tree individuals of heights $>130 \mathrm{~cm}$ and $<1 / 2$ the height of the trees of the main level, $5_{1 \mathrm{a}}$ - individuals of heights in range $25-130 \mathrm{~cm}, 5_{1 \mathrm{~b}}$ - individuals of heights $<25 \mathrm{~cm}, 5_{2}-$ seedlings with uterine petals. In grades $1-$ 4 average height, DBH and number of individuals were recorded for all tree species on the image area. For individual grades $5_{1 \mathrm{a}}, 5_{1 \mathrm{~b}}$ and $5_{2}$, the average number for each species per $1 \mathrm{~m}^{2}$ was stated. In 2016, this scale was modified for comparing both periods, where grades $5_{1 \mathrm{~b}}, 5_{1 \mathrm{a}}$ and part of the grade 4 were indicated as natural regeneration (data recalculated from 2016 to 1961 for threshold value of $\mathrm{DBH}=4 \mathrm{~cm}$ ) and classes $1-3$ and the rest of grade 4 as tree layer.

Table 1. Overview of the basic characteristics of permanent research plots (PRP) $1-5$.

\begin{tabular}{|c|c|c|c|c|c|c|c|c|c|c|c|}
\hline PRP & GPS & Age & $\begin{array}{l}\text { Height } \\
\text { [m] }\end{array}$ & $\begin{array}{l}\mathrm{DBH} \\
{[\mathrm{cm}]}\end{array}$ & $\begin{array}{c}\text { Volume } \\
{\left[\mathrm{m}^{3} \mathrm{ha}^{-1}\right]}\end{array}$ & $\begin{array}{c}\text { Altitude } \\
{[\mathrm{m}]}\end{array}$ & Exposure & $\begin{array}{c}\text { Gradient } \\
{\left[{ }^{0}\right]}\end{array}$ & Plant associations & Forest type & Soil type \\
\hline 1 & $\begin{array}{l}50^{\circ} 30^{\prime} 05.0^{\prime \prime} \mathrm{N} \\
16^{\circ} 11^{\prime} 57.6^{\prime \prime} \mathrm{E}\end{array}$ & 146 & 22 & 37 & 593 & 425 & SE & 45 & Aceri-Carpinetum & Combined forest & Leptosol skeletic \\
\hline 2 & $\begin{array}{l}50^{\circ} 30^{\prime} 10.5^{\prime \prime} \mathrm{N} \\
16^{\circ} 12^{\prime} 22.6^{\prime \prime} \mathrm{E}\end{array}$ & 162 & 25 & 44 & 591 & 435 & S & 29 & Asperulo-Fagetum & High forest & Cambisol skeletic \\
\hline 3 & $\begin{array}{l}50^{\circ} 29^{\prime} 57.1 ” \mathrm{~N} \\
16^{\circ} 12^{\prime} 17.4 ” \mathrm{E}\end{array}$ & 118 & 27 & 35 & 699 & 420 & $\mathrm{NE}$ & 36 & Tilio cordatae-Fagetum & High forest & Cambisol skeletic \\
\hline 4 & $\begin{array}{l}50^{\circ} 30^{\prime} 49.8^{\prime \prime} \mathrm{N} \\
16^{\circ} 12^{\prime} 49.0^{\prime \prime} \mathrm{E}\end{array}$ & 148 & 17 & 35 & 612 & 440 & W & 40 & Tilio cordatae-Fagetum & Combined forest & Leptosol calcaric \\
\hline 5 & $\begin{array}{l}50^{\circ} 30^{\prime} 09.5 " \mathrm{~N} \\
16^{0} 12^{\prime} 45.2 ” \mathrm{E}\end{array}$ & 73 & 18 & 26 & 340 & 430 & W & 28 & Mercuriali-Fraxinetum & Coppice & Leptosol calcaric \\
\hline
\end{tabular}

\subsection{Data collection}

Midpoints of permanent research plots (PRP) at Kozínek SAC were always located near the central tree of typological plots dating back to 1961. In 2016 Field-Map technology (IFER-Monitoring and Mapping Solutions Ltd.) was used to determine the structure of the tree layer of tree species in forest ecosystems on five PRP of $50 \times 50 \mathrm{~m}$ in size $\left(2,500 \mathrm{~m}^{2}\right)$. Using this system, the position of all tree layer individuals of breast height diameter $(\mathrm{DBH}) \geq 4 \mathrm{~cm}$ (to $1 \mathrm{~mm}$ accuracy) on five PRP and crown projections at a minimum of four directions perpendicular to each other were localized. In the tree layer tree heights and heights of live crown base were measured by a Vertex laser hypsometer (to $0.1 \mathrm{~m}$ accuracy).

In 2016 natural regeneration (seedlings older than 1 year, $\mathrm{DBH}<4 \mathrm{~cm}$ ) was measured on PRP in $10 \times 50 \mathrm{~m}$ $\left(500 \mathrm{~m}^{2}\right)$ transects that were representative with regard to regeneration. These characteristics of natural regeneration were measured: position, heights, heights of green crown base and crown width.

Phytocoenological relevés on PRP 1-5 were recorded in 1961 by Dr. Gregor according to the combined BraunBlanquet abundance/dominance scale as adapted and later published by Zlatník within the particular height layers (Zlatník 1978). The same modified methodology was used in 2016 by prof. Vacek. Scale used for the $1^{\text {st }}$ monitoring according to Zlatník (1978) was fallowing: 1 - predominant trees (dominant), 2 - main level trees,
In summary, herb layer on PRP was evaluated in circular plot around the central soil probe covering an area of $490 \mathrm{~m}^{2}(\mathrm{r}=12.5 \mathrm{~m})$ in both periods $(1961,2016)$. In 1961 , natural regeneration was evaluated in the same circular plot (size $490 \mathrm{~m}^{2} ; 500 \mathrm{~m}^{2}$ in 2016). In this year, tree layers were described and evaluated on a larger circular area with radius $\mathrm{r}=15 \mathrm{~m}$ ( $\operatorname{size} 707 \mathrm{~m}^{2} ; 2,500 \mathrm{~m}^{2}$ in 2016).

\subsection{Data processing}

Tree species and structural diversity were evaluated by following indices: species richness $D_{1}$ (Margalef 1958) and $D_{2}$ (Menhinick 1964), species heterogeneity $\lambda$ (Simpson 1949) and $H^{\prime}$ (Shannon 1948) and species evenness $E_{1}$ (Pielou 1975) and $E_{2}$ (Hill 1973). Structural and overall diversity was evaluated by these indices: Arten-profile index $A$ (Pretzsch 2006), diameter $T M_{d}$ and height differentiation index $T M_{h}$ (Füldner 1995), index of non-randomness $\alpha$ (Pielou 1959, Mountford 1961), aggregation index $R$ (Clark and Evans 1954) and total diversity index $B$ (Jaehne and Dohrenbusch 1997). The criteria for these indices are given in Table 2.

The program PointPro (Zahradník, ČZU) was used to calculate the characteristics describing the spatial pattern of the overstorey. The test of significance of deviations from expected values for the random arrangement of points was done by Monte Carlo simulations. Basic stand characteristics and structural diversity of the tree 
Table 2. Overview of indices describing the stand structure and their common interpretation.

\begin{tabular}{|c|c|c|c|c|}
\hline Criterion & Quantifiers & Label & Reference & Evaluation \\
\hline \multirow{4}{*}{ Species diversity } & Species richness & $\begin{array}{l}D_{1} \text { (Mai) } \\
D_{2} \text { (Mei) }\end{array}$ & $\begin{array}{l}\text { Margalef } 1958 \\
\text { Menhinick } 1964\end{array}$ & minimum $D=0$, higher $D=$ higher values \\
\hline & \multirow{2}{*}{ Species heterogeneity } & $\chi($ Sii) & Simpson 1949 & range $0-1 ;$ minimum $\chi=0$, maximum $\chi=1$ \\
\hline & & $H^{\prime}$ (Shi) & Shannon 1948 & minimum $H^{\prime}=0$, higher $H^{\prime}=$ higher values \\
\hline & Species evenness & $\begin{array}{l}E_{1}(\mathrm{Pii}) \\
E_{2}(\mathrm{Hi})\end{array}$ & $\begin{array}{l}\text { Pielou } 1975 \\
\text { Hill } 1973\end{array}$ & range $0-1 ;$ minimum $E=0$, maximum $E=1$ \\
\hline Vertical diversity & Arten-profile index & $A$ (Pri) & Pretzsch 2006 & $\begin{array}{c}\text { range } 0-1 \text {; balanced vertical structure } A<0.3 \text {; } \\
\text { selection forest } A>0.9\end{array}$ \\
\hline Structure differentiation & $\begin{array}{l}\text { Diameter diff. } \\
\text { Height diff. }\end{array}$ & $\begin{array}{l}T M_{d}(\mathrm{Fi}) \\
T M_{h}(\mathrm{Fi})\end{array}$ & Füldner 1995 & \multirow{3}{*}{$\begin{array}{c}\text { range } 0-1 \text {; low } T M<0.3 \text {; very high differentiation } T M>0.7 \\
\text { mean value } \alpha=1 \text {; aggregation } \alpha>1 \text {; regularity } \alpha<1 \\
\text { mean value } R=1 \text {; aggregation } R<1 \text {; regularity } R>1 \\
\text { monotonous structure } B<4 \text {; uneven structure } B=6-8 \text {; } \\
\text { very diverse structure } B>9\end{array}$} \\
\hline Horizontal structure & $\begin{array}{l}\text { Index of non-randomness } \\
\text { Aggregation index }\end{array}$ & $\begin{array}{l}\alpha(\mathrm{Pi} \& \mathrm{Mi}) \\
R(\mathrm{C} \& \mathrm{Ei})\end{array}$ & $\begin{array}{l}\text { Pielou 1959; Mountford } 1961 \\
\text { Clark \& Evans } 1954\end{array}$ & \\
\hline Complex diversity & Stand diversity & $B(J \& \mathrm{Di})$ & Jaehne \& Dohrenbusch 1997 & \\
\hline
\end{tabular}

layer were evaluated by the simulator SIBYLA (Fabrika \& Durský 2005). Based on the measured dendrometric data stand characteristics including stand volume (Petráš \& Pajtík 1991), stocking (Reinike 1933) and canopy density (crown closure and crown projection area) were computed. Localization figures were made in ARCGIS program (Esri). Ellenberg's indicator values (EIV) documenting ecological preferences of species were used for the interpretation of changes in environmental conditions. For each relevé unweighted means of EIV were computed for light, nutrients, moisture, soil reaction, temperature and continentality (Ellenberg et al. 1992). Analyses were processed in R software (R Core Team 2018). The differences in species diversity indices of tree layer, natural regeneration and vegetation cover between 1961 and 2016 and among research plots were separately tested by paired t-test. In addition, canopy of tree layer and herbal cover with species diversity were tested by the Pearson correlation coefficient. Unconstrained principal component analysis (PCA) in the CANOCO program (Šmilauer \& Lepš 2014) was used to analyse relationships among species diversity of tree layer, herb layer and natural regeneration and stand characteristics, canopy parameters, soil type, forest type, plant associations and time in order to reveal similarity of five PRP in course of time $(1961,2016)$. Data were centred and standardized during the analysis.

\section{Results}

\subsection{Tree layer structure}

In 2016, the number of live trees ranged from 240 to 720 trees ha ${ }^{-1}$ with the stand density index (SDI) 0.70 $\pm 0.09 \mathrm{SD}$ (Table 3 ). The stand volume was $340-$ $699 \mathrm{~m}^{3} \mathrm{ha}^{-1}$ in 2016 , the highest stand volume of $699 \mathrm{~m}^{3} \mathrm{ha}^{-1}$ was on PRP 3 and the lowest volume of $340 \mathrm{~m}^{3} \mathrm{ha}^{-1}$ was on PRP 5. The tree layer was composed by three dominant species: European beech (Fagus sylvatica L.), Sycamore maple (Acer pseudoplatanus L.) and small-leaved lime (Tilia cordata Mill.; Table 3, Fig. 2). Beech was the dominant species on all research plots with the exception of PRP 5. On PRP 2 its volume share was nearly $99 \%$ almost without any admixture, on PRP 4 than $83 \%$. The maple was dominantly abundant on PRP 5 (42\%), while on other plots without PRP1 (18\%) maple did not exceed $4 \%$. Lime was relatively abundant on PRP $3(35 \%)$, while on other plots it reached the maximum of 4\%. The share of other tree species (Carpinus betulus L., Picea abies [L.] Karst., Quercus petraea [Matt.] Liebl.)

Table 3. Basic stand characteristics of permanent research plots $1-5$ in 2016.

\begin{tabular}{|c|c|c|c|c|c|c|c|c|c|c|c|c|}
\hline PRP & Age & Crown closure & $\begin{array}{c}\text { Crown projection } \\
\text { [ha] }\end{array}$ & $\begin{array}{l}\text { Stand density } \\
\text { index }\end{array}$ & $\frac{\text { PAI }}{\left[\mathrm{m}^{3} \mathrm{~h}\right.}$ & $\frac{\text { MAI }}{\left.{ }^{-1} \mathrm{y}^{-1}\right]}$ & Tree species ${ }^{1)}$ & $\begin{array}{l}\text { Height } \\
{[\mathrm{m}]}\end{array}$ & $\begin{array}{l}\mathrm{DBH} \\
{[\mathrm{cm}]}\end{array}$ & $\begin{array}{c}\text { Stand volume } \\
{\left[\mathrm{m}^{3} \mathrm{ha}^{-1}\right]}\end{array}$ & $\begin{array}{c}\text { Number } \\
\text { of trees } \\
{\left[\text { trees ha }{ }^{-1}\right]}\end{array}$ & $\begin{array}{c}\text { Basal area } \\
{\left[\mathrm{m}^{2} \mathrm{ha}^{-1}\right]}\end{array}$ \\
\hline \multirow{6}{*}{1} & \multirow{6}{*}{146} & \multirow{6}{*}{0.94} & \multirow{6}{*}{3.48} & \multirow{6}{*}{0.76} & \multirow{6}{*}{6.8} & \multirow{6}{*}{4.1} & E. beech & 26.2 & 47.9 & 274 & 104 & 18.6 \\
\hline & & & & & & & S. maple & 27.8 & 55.0 & 108 & 32 & 7.5 \\
\hline & & & & & & & E. hornbeam & 20.6 & 33.3 & 80 & 88 & 7.6 \\
\hline & & & & & & & N. maple & 20.6 & 28.4 & 43 & 56 & 3.5 \\
\hline & & & & & & & S. elm & 17.8 & 28.5 & 41 & 68 & 4.3 \\
\hline & & & & & & & E. ash & 23.3 & 31.7 & 28 & 36 & 2.8 \\
\hline \multirow[t]{2}{*}{2} & \multirow[t]{2}{*}{162} & \multirow[t]{2}{*}{0.87} & \multirow[t]{2}{*}{2.28} & \multirow[t]{2}{*}{0.55} & \multirow[t]{2}{*}{7.0} & \multirow[t]{2}{*}{3.6} & E. beech & 28.9 & 49.5 & 582 & 184 & 35.4 \\
\hline & & & & & & & E. beech & 28.7 & 38.1 & 417 & 240 & 27.3 \\
\hline \multirow[t]{3}{*}{3} & \multirow[t]{3}{*}{118} & \multirow[t]{3}{*}{0.94} & \multirow[t]{3}{*}{3.21} & \multirow[t]{3}{*}{0.79} & \multirow[t]{3}{*}{8.2} & \multirow[t]{3}{*}{5.9} & S-l. lime & 27.4 & 34.8 & 246 & 176 & 16.7 \\
\hline & & & & & & & S. maple & 23.7 & 27.8 & 27 & 36 & 2.1 \\
\hline & & & & & & & E. beech & 16.8 & 38.0 & 505 & 300 & 33.9 \\
\hline \multirow[t]{4}{*}{4} & 148 & 0.92 & 2.93 & 0.71 & 6.5 & 4.1 & N. spruce & 27.4 & 43.2 & 69 & 44 & 6.4 \\
\hline & & & & & & & S. fir & 31.3 & 47.9 & 28 & 12 & 2.1 \\
\hline & & & & & & & S. maple & 18.7 & 25.7 & 142 & 288 & 14.9 \\
\hline & & & & & & & E. beech & 18.1 & 32.4 & 53 & 64 & 5.2 \\
\hline 5 & 73 & 0.90 & 2.63 & 0.71 & 8.9 & 5.4 & S. oak & 19.2 & 32.0 & 46 & 64 & 5.1 \\
\hline & & & & & & & S. birch & 17.5 & 23.2 & 27 & 88 & 3.7 \\
\hline & & & & & & & S. fir & 22.1 & 31.7 & 17 & 20 & 1.5 \\
\hline
\end{tabular}


PRP 1

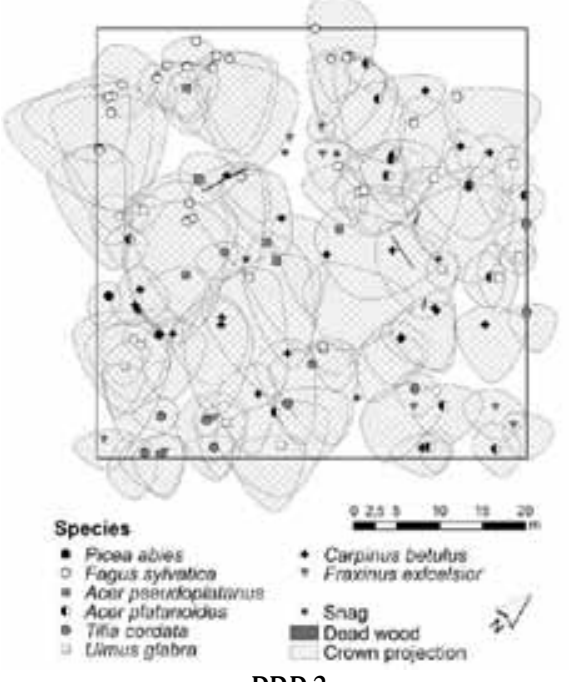

PRP 3

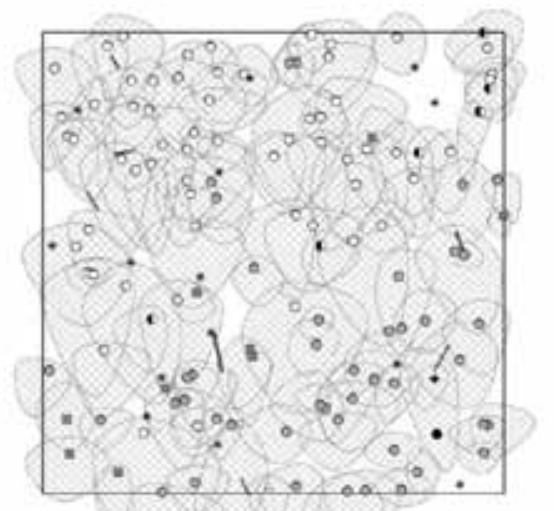

Species

- Pices abies

- Faguis sylvatica

- Acer platanondes

- Carminus botules

- Carpinus botules

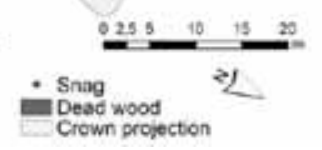

PRP 2

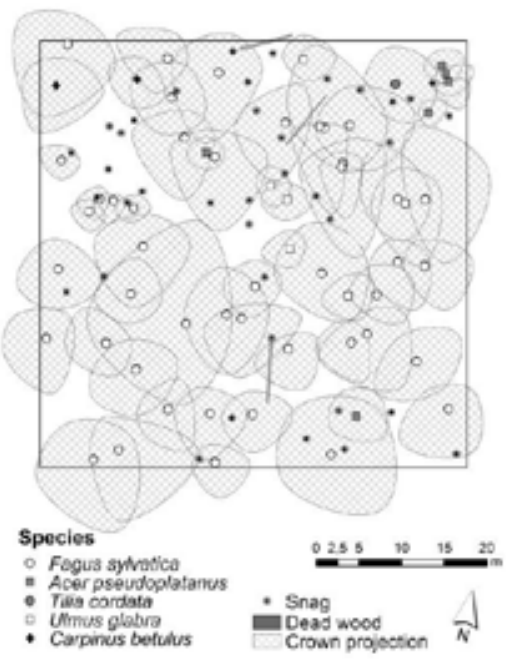

PRP 4

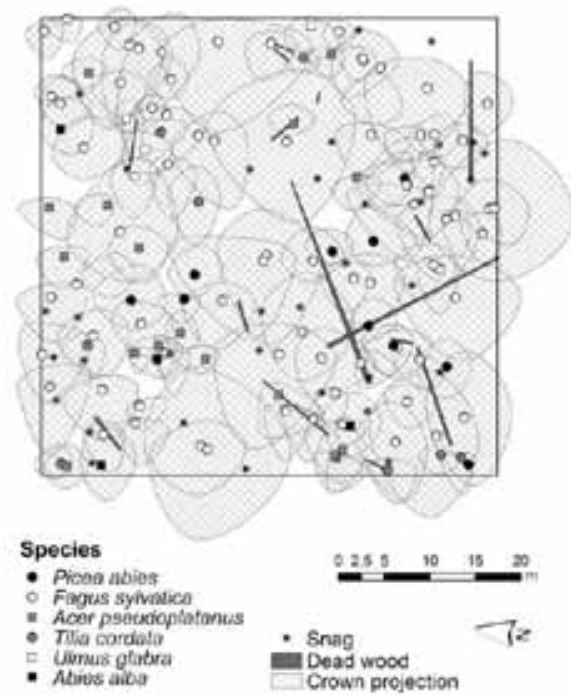

PRP 5

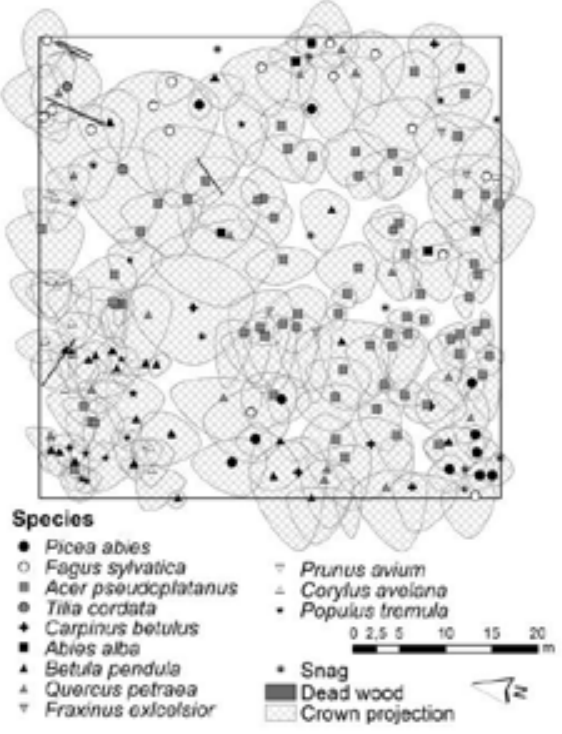

Fig. 2. Horizontal structure of forest stands on permanent research plots $1-5$ in 2016. 
ranged from 0 to $13 \%$. Average basal area in 2016 was $36.7-47.0 \mathrm{~m}^{2} \mathrm{ha}^{-1}$, periodic annual increment (PAI) ranged from 6.5 to $8.9 \mathrm{~m}^{3} \mathrm{ha}^{-1} \mathrm{y}^{-1}$ and mean annual increment (MAI) was 3.6-5.9 $\mathrm{m}^{3} \mathrm{ha}^{-1} \mathrm{y}^{-1}$.

Spatial pattern of tree layer on PRP 1 was aggregated according to both indices (Table 4), however it was not statistically significant in the case of $R$. On PRP 2 the horizontal structure of tree layer was regular (not significant by $\alpha$ ). On PRP $3-5$ the horizontal structure of individuals of tree layer was random to regular. The vertical structure of tree layer was distinctly diversified on PRP 1 and 2 according to $A$, on PRP 3 and 4 it was moderately differentiated and on PRP 5 it was weakly diversified. According to $T M_{d}$ diameter differentiation was medium on all PRP while $T M_{h}$ height differentiation was low on PRP 1, 3 and 5, and on PRP 2 and 4 it was medium. With respect to tree layer, PRP 1, 3 and 5 represented an extraordinarily diversified stand structure on, while the structural diversity on PRP 4 and 2 was considerably lower.

Table 4. Structural diversity of tree layer on permanent research plots $1-5$ in 2016.

\begin{tabular}{lcccccc}
\hline PRP & $A(\mathrm{Pri})$ & $T M_{d}(\mathrm{Fi})$ & $T M_{h}(\mathrm{Fi})$ & $\alpha$ (Pi\&Moi) & $R(\mathrm{C} \& \mathrm{Ei})$ & $B(\mathrm{~J} \& \mathrm{Di})$ \\
\hline 1 & 0.718 & 0.371 & 0.296 & $1.620^{*}$ & 0.865 & 10.339 \\
2 & 0.252 & 0.364 & 0.305 & 0.806 & $1.341^{*}$ & 7.088 \\
3 & 0.497 & 0.369 & 0.266 & 0.980 & 1.083 & 9.272 \\
4 & 0.546 & 0.496 & 0.429 & 1.085 & 1.057 & 8.648 \\
5 & 0.674 & 0.374 & 0.289 & 1.173 & 1.072 & 11.277 \\
\hline
\end{tabular}

Notes: $A$ - Arten-profile index, $T M_{d}$ - diameter differentiation index, $T M_{h}$ - height differentiation index, $\alpha$-index of non-randomness, $R$ - aggregation index, $B$ - total diversity index; *statistically significant $(0.95$ confidence interval) for spatial pattern $-\mathrm{R}$ and $\alpha$ indexes. .

\subsection{Species diversity of tree layer}

The species richness according to tree layer $D_{1}$ was high on PRP 1, 3 and 5 and it was medium on PRP 2 and 4 in 1961 (Table 5). Until 2016 a moderate increase of species diversity was observed on all PRP. Tree layer $D_{2}$ was medium in 1961 on PRP 1, 3 and 5 and it was low on PRP 2 and 4. Until 2016 its slight to moderate increase to a medium level was found out on all PRP. In 1961 the species heterogeneity according tree layer $\lambda$ was high on PRP 1, 3, 4 and 5 and medium on PRP 2. Over 55 years it moderately increased on PRP 5, on PRP 2-4 it decreased moderately. Tree layer entropy $H^{\prime}$ was high in 1961 on PRP 1 and 5, and it was medium on PRP $2-4$. Until
2016 it moderately increased on PRP 5, and it decreased slightly to moderately on PRP 2 - 4. In 1961, the species evenness according to tree layer $E_{1}$ indicated high biodiversity on PRP 1, 4 and 5, on PRP 2 and 3 medium biodiversity; in 2016 the species eveness was the same on PRP 1 and it moderately decreased on PRP $2-5$. Tree layer $E_{2}$ index indicated high biodiversity on PRP 1 and 3 in 1961 while medium diversity was recorded on PRP 2, 4 and 5. Until 2016 it moderately increased on PRP 3 whereas it moderately decreased on the other plots.

Comparing species diversity of tree layer in 1961 and 2016 , forest stands showed several differences. In the course of 55 years, species richness in tree layer increased significantly (parameter $D_{2}$, paired $\mathrm{t}-$ test, $\mathrm{t}=-7.22, \mathrm{df}=$ $4, p=0.002$ ), but no significant changes were observed in species heterogeneity ( $p>0.05$ in all cases). In terms of species evenness, there was found marginal insignificance in terms of decrease (parameter $E_{1}$, paired t-test, $\mathrm{t}=2.41, \mathrm{df}=4, \mathrm{p}=0.07)$. Overall, the most substantial change occurred in coppice on PRP 5, where the species diversity increased by $17.3 \%$, conversely high forest on PRP 3 showed its stability in diversity during study period (decrease $-0.4 \%$ ). The highest diversity was on PRP 5 and 1, while the lowest diversity was observed on PRP 2 representing high forest.

\subsection{Species diversity of natural regeneration}

The density of natural regeneration ranged on studied PRP from 13,880 recruits ha ${ }^{-1}$ on PRP 4 to 186,462 recruits ha ${ }^{-1}$ on PRP 2 with increasing share of maples and European ash compared to tree layer. Natural regeneration $D_{1}$ (species richness) was high on PRP 1, 3 and 5 in 1961 whereas it was medium on PRP 2 and 4 (Table 6). Until 2016 it substantially increased on PRP 4, it was the same on PRP 2, on PRP 3 and 5 there was a moderate decrease and on PRP 1 a distinct decrease. Natural regeneration $D_{2}$ was medium on PRP 1 in 1961 , low on PRP 2 - 4 and very low on PRP 5. Until 2016 it substantially decreased on PRP $1-3$ while it decreased moderately on PRP 4 and 5. In 1961 natural regeneration $\lambda$ (species heterogeneity) was high on PRP 1, 3, 4 and 5 and medium on PRP 2. Over 55 years it increased moderately on PRP 2 and 4 while vice versa on PRP 1, 3 and 5. Natural regeneration entropy $H^{\prime}$ was high in

Table 5. Change of species diversity of tree layer on permanent research plots $1-5$ from 1961 to 2016.

\begin{tabular}{|c|c|c|c|c|c|c|c|c|c|c|c|c|}
\hline PRP & Year & $n$ (ind) & & $D_{1}$ (Mai) & $D_{2}(\mathrm{Mei})$ & & $\chi$ (Sii) & $H^{\prime}$ (Shi) & & $E_{1}(\mathrm{Pii})$ & $E_{2}(\mathrm{Hi})$ & \\
\hline \multirow{2}{*}{1} & 1961 & 8 & \multirow[b]{2}{*}{$\rightarrow$} & 1.105 & 0.337 & \multirow[b]{2}{*}{$\nearrow$} & 0.837 & 1.908 & \multirow[b]{2}{*}{$\nearrow$} & 0.917 & 0.892 & \multirow[b]{2}{*}{$\searrow$} \\
\hline & 2016 & 8 & & 1.155 & 0.387 & & 0.836 & 1.912 & & 0.920 & 0.885 & \\
\hline \multirow{2}{*}{2} & 1961 & 4 & & 0.525 & 0.229 & \multirow{2}{*}{$\nearrow$} & 0.477 & 0.911 & \multirow{2}{*}{$\searrow$} & 0.657 & 0.613 & \multirow{2}{*}{ y } \\
\hline & 2016 & 5 & $\nearrow$ & 0.730 & 0.323 & & 0.394 & 0.823 & & 0.511 & 0.509 & \\
\hline \multirow{2}{*}{3} & 1961 & 7 & & 0.919 & 0.268 & \multirow[b]{2}{*}{$\nearrow$} & 0.662 & 1.342 & \multirow[b]{2}{*}{$\searrow$} & 0.689 & 0.693 & \multirow[b]{2}{*}{$\searrow$} \\
\hline & 2016 & 7 & $\rightarrow$ & 0.969 & 0.317 & & 0.620 & 1.175 & & 0.604 & 0.729 & \\
\hline \multirow{2}{*}{4} & 1961 & 6 & & 0.762 & 0.225 & \multirow[b]{2}{*}{$\nearrow$} & 0.672 & 1.420 & \multirow[b]{2}{*}{$\searrow$} & 0.793 & 0.653 & \multirow[b]{2}{*}{$\searrow$} \\
\hline & 2016 & 6 & $\rightarrow$ & 0.812 & 0.276 & & 0.559 & 1.172 & & 0.654 & 0.568 & \\
\hline \multirow{2}{*}{5} & 1961 & 7 & & 1.031 & 0.382 & \multirow{2}{*}{$\nearrow$} & 0.723 & 1.566 & \multirow{2}{*}{$\nearrow$} & 0.805 & 0.690 & \multirow{2}{*}{$\searrow$} \\
\hline & 2016 & 13 & 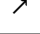 & 1.672 & 0.447 & & 0.794 & 1.975 & & 0.795 & 0.620 & \\
\hline
\end{tabular}

Notes: $n$ - number of species, $D_{1}$ and $D_{2}$ - indexes of species richness, $\chi$ and $H^{\prime}$ - indexes of species heterogeneity, $E_{1}$ and $E_{2}-$ indexes of species evenness; code abbreviation of species diversity tendency over 55 years: $\searrow$ decreasing index value, $\supset$ increasing index value, $\rightarrow$ no change index value. 
1961 on PRP 1, 3 - 5, and medium on PRP 2. Until 2016 there was a moderate increase on PRP 2 and 4, a substantial decrease on PRP 1 and 5, and a moderate decrease on PRP 3. Natural regeneration $E_{1}$ (species evenness) indicated in 1961 high biodiversity on PRP 1, 3- 5 and medium biodiversity on PRP 2. Over 55 years it slightly increased on PRP 2 while it moderately decreased on PRP 1, 3-5. Natural regeneration $E_{2}$ indicates in 1961 high biodiversity on PRP 1, 3-5 and medium biodiversity on PRP 2. Until 2016 it moderately increased on PRP 2, it was the same on PRP 4, on PRP 1 and 3 it moderately decreased and on PRP 5 it substantially decreased.

Comparing species diversity of natural regeneration in 1961 and 2016, plots showed also several significant differences, similarly such as in tree layer. Comparing PRP at the beginning and the end of the observation period, there were significant decrease in species richness trough all PRP (parameter $D_{2}$, paired t-test, $\mathrm{t}=2.8$, $\mathrm{df}=4, \mathrm{p}=0.049)$. No significant changes were observed in species heterogeneity $(\mathrm{p}>0.05)$, while marginal insignificance was found in species evenness (parameter $E_{1}$, paired $\mathrm{t}$-test, $\mathrm{t}=2.17, \mathrm{df}=4, \mathrm{p}=0.10)$. Overall, the most substantial change occurred on PRP 1, where the species diversity decreased by $41.9 \%$, conversely PRP 4 showed its stability in diversity for 55 years (increase $4.2 \%$ ). The highest species diversity was in coppice with standards on PRP 4, while the lowest diversity was observed in high forest on PRP 2.

\subsection{Species diversity of herb layer}

The species richness of herb layer was high in 1961 on PRP $1-3$ and very high on PRP 4 and 5 (Table 7). Until 2016 it increased rather substantially on PRP $1-4$, only on PRP 5 it moderately decreased. Herb layer $\chi$ (species heterogeneity) was high in PRP 1 - 5 in 1961. Until 2016 there was a moderate increase on PRP 2 and 3, and it decreased moderately on PRP 1 . Herb layer entropy $H^{\prime}$ was high in 1961 on PRP 4, and medium on PRP 1 - 3 and 5. Until 2016 it increased moderately on PRP 2 - 4, while opposite dynamics were on PRP 1 and 5 . Herb layer $E_{1}$ (species evenness) indicated in 1961 high biodiversity on PRP 4 and medium biodiversity on PRP $1-3$ and 5 while in 2016 it moderately decreased on all PRP. Herb layer $E_{2}$ indicated in 1961 high biodiversity on PRP 4 and medium biodiversity on PRP $1-3$ and 5. Until 2016 it moderately increased on PRP 3 and 5, and it moderately decreased on PRP 1 and 2.

Comparing species diversity of herb layer in 1961 and 2016, PRP showed no significant difference. Species richness showed marginal insignificance in term of increase (parameter $D_{1}$, paired $\mathrm{t}$-test, $\mathrm{t}=-2.6, \mathrm{df}=4$, $\mathrm{p}=0.06$ ) and no significant changes were observed in species evenness and especially in species heterogeneity (parameter $H^{\prime}$, paired $\mathrm{t}$-test, $\mathrm{t}=0.03, \mathrm{df}=4, \mathrm{p}=0.98$ ). Overall, the most substantial change in species diversity occurred in high forest on PRP 3 (increase 11.2\%), respectively the minimum changes in coppice on PRP 5 (decrease $-2.0 \%$ ), both conversely than in tree layer and natural regeneration. The highest species diversity was on PRP 4, while the lowest diversity on PRP 3 in 1961, respectively on PRP 1 in 2016.

Retreating species were mainly light demanding ones like Veronica chamaedrys agg., Hypericum hirsutum, Melica nutans and Fragaria vesca. Partly disappeared also species typical for broadleaved forests like Lilium martagon, Viola mirabilis and Poa nemoralis and also cold-tolerant species (Actaea spicata, Campanulatrache-

Table 6. Change of species diversity of natural regeneration on permanent research plots $1-5$ from 1961 to 2016.

\begin{tabular}{|c|c|c|c|c|c|c|c|c|c|c|c|c|}
\hline PRP & Year & $n$ (ind) & & $\overline{D_{1} \text { (Mai) }}$ & $D_{2}$ (Mei) & & $\chi($ Sii) & $H^{\prime}$ (Shi) & & $E_{1}$ (Pii) & $E_{2}(\mathrm{Hi})$ & \\
\hline \multirow{2}{*}{1} & 1961 & 9 & \multirow[b]{2}{*}{$\searrow$} & 1.227 & 0.345 & \multirow{2}{*}{$\searrow$} & 0.824 & 1.844 & \multirow[b]{2}{*}{$\searrow$} & 0.839 & 0.880 & \multirow{2}{*}{ 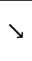 } \\
\hline & 2016 & 8 & & 0.657 & 0.039 & & 0.608 & 1.219 & & 0.586 & 0.651 & \\
\hline \multirow{2}{*}{2} & 1961 & 7 & & 0.831 & 0.189 & \multirow[b]{2}{*}{$\searrow$} & 0.476 & 1.015 & \multirow[b]{2}{*}{$\nearrow$} & 0.522 & 0.517 & \multirow[b]{2}{*}{$\nearrow$} \\
\hline & 2016 & 13 & $\nearrow$ & 0.824 & 0.025 & & 0.691 & 1.397 & & 0.583 & 0.735 & \\
\hline \multirow{2}{*}{3} & 1961 & 7 & & 0.967 & 0.214 & \multirow[b]{2}{*}{$\searrow$} & 0.715 & 1.505 & \multirow[b]{2}{*}{$\searrow$} & 0.724 & 0.717 & \multirow[b]{2}{*}{$\searrow$} \\
\hline & 2016 & 11 & $\nearrow$ & 0.880 & 0.038 & & 0.599 & 1.158 & & 0.483 & 0.685 & \\
\hline \multirow[b]{2}{*}{4} & 1961 & 7 & & 0.767 & 0.140 & \multirow[b]{2}{*}{$\nearrow$} & 0.687 & 1.372 & \multirow[b]{2}{*}{$\tau$} & 0.705 & 0.745 & \multirow[b]{2}{*}{ y } \\
\hline & 2016 & 11 & $\nearrow$ & $\begin{array}{l}0.101 \\
1.048\end{array}$ & $\begin{array}{l}0.140 \\
0.093\end{array}$ & & $\begin{array}{l}0.001 \\
0.750\end{array}$ & 1.612 & & 0.672 & 0.746 & \\
\hline \multirow{2}{*}{5} & 1961 & 13 & & 1.301 & 0.095 & \multirow[b]{2}{*}{$\searrow$} & 0.821 & 2.001 & \multirow[b]{2}{*}{$\searrow$} & 0.758 & 0.718 & \multirow[b]{2}{*}{$\searrow$} \\
\hline & 2016 & 13 & $\rightarrow$ & $\begin{array}{l}1.001 \\
1.159\end{array}$ & 0.074 & & 0.550 & 1.339 & & 0.522 & 0.433 & \\
\hline
\end{tabular}

Notes: $n$ - number of species, $D_{1}$ and $D_{2}$ - indexes of species richness, $\chi$ and $H^{\prime}$ - indexes of species heterogeneity, $E_{1}$ and $E_{2}-$ indexes of species evenness; code abbreviation of species diversity tendency over 55 years: $\searrow$ decreasing index value, $>$ increasing index value, $\rightarrow$ no change index value.

Table 7. Change of species diversity of herb layer on permanent research plots 1-5 from 1961 to 2016.

\begin{tabular}{|c|c|c|c|c|c|c|c|c|c|c|c|c|}
\hline PRP & Year & $n$ (ind) & & $D_{1}$ (Mai) & $D_{2}$ (Mei) & & $\chi$ (Sii) & $H^{\prime}$ (Shi) & & $E_{1}(\mathrm{Pii})$ & $E_{2}(\mathrm{Hi})$ & \\
\hline \multirow{2}{*}{1} & 1961 & 19 & \multirow[b]{2}{*}{$\nearrow$} & 4.801 & 2.915 & \multirow[b]{2}{*}{$\nearrow$} & 0.822 & 2.053 & \multirow[b]{2}{*}{$\searrow$} & 0.697 & 0.680 & \multirow[b]{2}{*}{$\searrow$} \\
\hline & 2016 & 26 & & 6.759 & 4.091 & & 0.688 & 1.746 & & 0.536 & 0.633 & \\
\hline \multirow{2}{*}{2} & 1961 & 16 & & 3.744 & 1.859 & \multirow[b]{2}{*}{$\nearrow$} & 0.792 & 1.866 & \multirow[b]{2}{*}{$\nearrow$} & 0.646 & 0.699 & \multirow[b]{2}{*}{$\searrow$} \\
\hline & 2016 & 24 & $\nearrow$ & 5.008 & 2.415 & & 0.812 & 2.015 & & 0.634 & 0.663 & \\
\hline \multirow{2}{*}{3} & 1961 & 14 & & 3.150 & 1.778 & \multirow[b]{2}{*}{$\nearrow$} & 0.779 & 1.922 & \multirow[b]{2}{*}{$\nearrow$} & 0.728 & 0.604 & \multirow[b]{2}{*}{$\nearrow$} \\
\hline & 2016 & 23 & $\nearrow$ & 4.918 & 2.457 & & 0.835 & 2.191 & & 0.699 & 0.639 & \\
\hline \multirow[b]{2}{*}{4} & 1961 & 33 & & 9.160 & 5.753 & \multirow[b]{2}{*}{$\nearrow$} & 0.939 & 3.008 & \multirow[b]{2}{*}{$\nearrow$} & 0.860 & 0.799 & \multirow[b]{2}{*}{$\searrow$} \\
\hline & 2016 & 38 & $\nearrow$ & 10.374 & 6.387 & & 0.942 & 3.073 & & 0.845 & 0.794 & \\
\hline \multirow[b]{2}{*}{5} & 1961 & 41 & & 9.033 & 4.479 & \multirow[b]{2}{*}{$\searrow$} & 0.863 & 2.587 & \multirow[b]{2}{*}{$\searrow$} & 0.697 & 0.513 & \multirow{2}{*}{$\nearrow$} \\
\hline & 2016 & 40 & $\searrow$ & 8514 & 4049 & & 0858 & 2396 & & 0649 & 0.605 & \\
\hline
\end{tabular}

Notes: $n$ - number of species, $D_{1}$ and $D_{2}$ - indexes of species richness, $\chi$ and $H^{\prime}$ - indexes of species heterogeneity, $E_{1}$ and $E_{2}$ - indexes of species evenness; code abbreviation of species diversity tendency over 55 years: $\searrow$ decreasing index value, $\supset$ increasing index value, $\rightarrow$ no change index value. 
lium, Abies alba, Picea abies). On the contrary, increase was confirmed in the case of shade tolerant species like Athyrium filix-femina, Geum urbanum, Viola reichenbachiana and seedlings of tree species (Fagus sylvatica, Acer pseudoplatanus, Fraxinus excelsior, Ulmus glabra). Increase in case of thermophilic plants was also observed (Heptica nobilis, Isopyrum thalictroides, Acer platanoides, Carpinus betulus). From nitrophilous species increase was also recorded (Urtica dioica, Galeobdolon montanum and invasive Impatiens parviflora).

\subsection{Relationships among species diversity and stand characteristics}

Results of the PCA analysis are presented in the form of the ordination diagram in Fig. 3. The first ordination axis explained $32.8 \%$, the first two axes together $57.3 \%$ and the first four axes together $85.1 \%$ variability data. The first axis x represented age, volume and canopy of tree layer, but also species richness of regeneration. Second axis y represented regeneration canopy with species evenness of regeneration. All indices of stand species diversity positively correlated to each other, while these parameters were negatively correlated with degree of naturalness (closer to autochthonous stands), regeneration canopy and species evenness of herb layer. Volume, age and canopy of tree layer were increasing in the course of time, while species diversity of regeneration and species richness of vegetation were decreasing in time. Canopy of tree layer were negatively correlated with regeneration $D_{1}(r=-0.70, p<0.05), \lambda(r=-0.63, p<0.05)$ and $H^{\prime}(r=-0.75, p<0.01)$ and regeneration canopy $(r=-0.64, p<0.05)$. Cover herb was negatively correlated with species diversity of natural regeneration and herb too, especially herb layer $\lambda(r=-0.79, p<0.01)$ and $H^{\prime}(r=-0.70, p<0.05)$ and regeneration $E_{2}(r=-0.74$, $p<0.01)$. Species indices of individual layers (herb, tree, natural regeneration) were often very significantly correlated $(p<0.001)$, in the greatest extent in the tree layer. The dynamics of parameters in the course of 55 years was remarkable especially for coppice stands on the PRP 5, as marks of each record are relatively distant from one another, whereas marks for PRP 2 and 3 representing the high forests were relatively close together in the diagram. Slope and regeneration richness had relatively small importance for the explanation of the data variability. PRP were very different amongst one another; high forests on skeletic cambisol occupied the right part of the diagram typical for higher stand volume and age of tree layer, coppice or combined forest (coppice with standard) on leptosols were characterized by higher species diversity. According to the plant associations the greatest overall species diversity was observed at Mercuriali-Fraxinetum, the lowest at Asperulo-Fagetum.

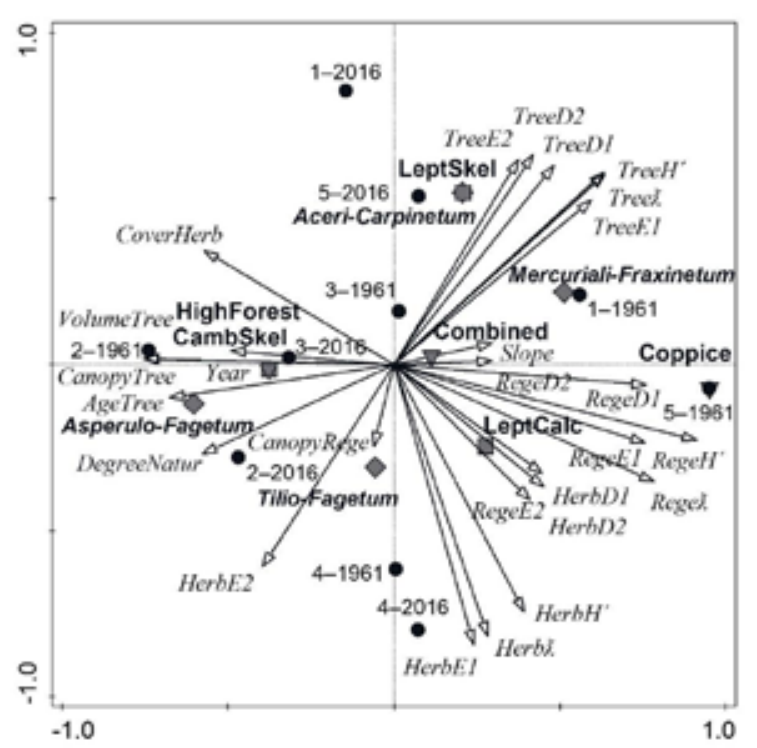

Fig. 3. Ordination diagram showing results of PCA analysis of relationships among species diversity of tree layer, herb layer and natural regeneration (E1 and $E 2$ species richness, $H^{\prime}$ and $\lambda$ species heterogenity, $D 1$ and $D 2$ species evenness, Rege natural regeneration); stand characteristics (AgeTree mean age of stand, VolumeTree stand volume, Slope of plot); canopy parameters (CanopyRege, CanopyTree, CoverHerb); soil type (CambSkel Cambisol Skeletic, LeptSkel Leptosol Skeletic, LeptCalc Leptosol Calcaric); forest type (Coppice, High Forest, Combined variant of the previous two type), plant associations (Tilio cordatae-Fagetum, Aceri-Carpinetum, Asperulo-Fagetum, Mercuriali-Fraxinetum) and time (Year). Code abbreviation: - identification of PRP and year of the record (1961, 2016), plant associations, $\mathbf{\square}$ soil type and $\boldsymbol{\nabla}$ forest type.

\section{Discussion}

\subsection{Structure and diversity of tree layer}

Based on our results, the stand volume ranged from $340 \mathrm{~m}^{3} \mathrm{ha}^{-1}$ on PRP 5 (coppice forest) to $699 \mathrm{~m}^{3} \mathrm{ha}^{-1}$ on PRP 3 (high forest) in 2016. Similarly, the highest timber production was observed in high forest in Český kras PLA, respectively the lowest stand volume in coppice (Vacek et al. 2019b). In relation to spatial distribution, pronounced variability of the horizontal structure of tree layer has been revealed. On PRP 1 the structure was aggregated, on PRP 2 it was regular and on PRP $3-5$ random to regular. Our results are consistent with those of Szwagrzyk \& Czerwczak (1993), who studied tree distribution in old-growth forest stands in the Czech Republic and in Poland. They stated that the dominant spatial distribution of trees tends to be between random and regular arrangement. Similar results for trees with diameter at breast height larger than $35 \mathrm{~cm}$ from nearnatural forest were reported by Szwagrzyk et al. (1997). Also, von Oheim et al. (2007) reported random distribution of canopy-forming full-grown trees on 8 ha of near-natural forest in north-eastern Germany. Similar 
results from the beech forest of Sudeten range in the Czech Republic and Poland are reported by Vacek et al. (2014a, 2015c) and Bulušek et al. (2016). The total stand diversity was the highest in coppice (PRP 5), while the lowest was observed in high forest (PRP 2). The lowest biodiversity was also documented in lowland forest in middle Bohemia, although the highest total diversity was found in coppice with standards (Vacek et al. 2019b).

For the tree layer (such as herb layer), the highest number of species was recorded on PRP 5 in 2016. It is a plot in the scree forest that can be classified as overgrown coppice because $58 \%$ of the trees originated from shoots. In spite of its lowest age the forest stand on this plot has very high biodiversity. This trend, but less pronounced, was observed on the other plots in scree forests, especially on PRP 1 with $20 \%$ of the trees of vegetative origin and on PRP 4 with $8 \%$ of the trees of vegetative origin. There was an opposite trend in the herb-rich beech forest stand on PRP 2 (high forest).

On PRP $1-4$ the number of species in the tree layer has not changed at all. A pronounced change has occurred only on PRP 5, where their number has increased almost to a double, which is caused by taking the relevés of forest stand shortly after coppicing when some species of trees have not grown up to the tree layer yet. Generally, species richness of tree layer significantly increased, while species evenness decreased during the observed 55 years. Comparable trend was observed from lowland stands during forest dynamics of 15 years (Vacek et al. 2019b). Overall, the most substantial change (diversity increase by $17 \%$ ) occurred in coppice on PRP 5. Conversely, studies from Denmark (Strandberg et al. 2005) and in Italy (Ciancio et al. 2006) showed decreasing biodiversity trend in coppice forests.

\subsection{Diversity of natural regeneration}

On PRP 2 - 4 number of natural regeneration species increased by $57-86 \%$, on PRP 5 it remained the same and on PRP 1 it decreased by $11 \%$. The highest increase in the number of natural regeneration species was observed in herb-rich beech forest. On all plots except PRP 5 the number of individuals of particular species of natural regeneration increased several times. The increase of the beech natural regeneration over the past two decades was also documented by many researches in the Sudeten range (Vacek et al. 2015a; Slanař et al. 2017). Expansion of beech can be explained by air pollution load (high $\mathrm{SO}_{2}$ concentrations) fading from the 80's and 90's (Králíček et al. 2017; Vacek et al. 2017a; Šimůnek et al. 2019) and tree species distribution shift due to climatic change (Kramer et al. 2010; Dulamsuren et al. 2017). The highest species diversity was in coppice with standards (PRP 4), while the lowest diversity was observed in high forest (PRP 2).
In the studied locality partial eutrophication of vegetation have taken place since 1961 (Hédl et al. 2010). Among the commonly appearing tree seedlings, newly occur Fraxinus excelsior, Ulmus glabra and Acer sp. that further contribute by their litterfall to eutrophication (Hofmeister et al. 2004). The trend of nutrient increase in the environment is evident from a comparison of EIV for nutrients and from soil analyses. The trend of eutrophication is very frequent in lowland forests (Van Calster et al. 2007; Keith et al. 2009). It is due to two factors that started to act approximately at the same time and that cannot be fully separated from each other. One factor is atmospheric deposition of nitrogen that has increased twice since the mid-20 ${ }^{\text {th }}$ century (Falkengren-Grerup 1995; Dentener et al. 2006; Hůnová et al. 2017), the other is a change in the management regime (Rackham 2008; Verheyen et al. 2012). Unlike the previous intensive removal of biomass, now organic matter remains in the environment and is accumulated there (Dzwonko \& Gawroński 2002). Eutrophication is also fostered by the above-mentioned higher representation of tree species requiring more nutrients in the environment (Hofmeister et al. 2004).

Generally, newly appearing were shade-tolerant trees seedlings. On the other side in relation to climate change, increase occurrence of Acer platanoides and Carpinus betulus and decrease of Abies alba and Picea abies was observed in natural regeneration and may be closely related to rising temperature in study area. Decline of Picea abies in middle-elevations and increase of broadleaved lowland tree species due to climatic change was observed also in other studies (Falk \& Hempelmann 2013; Sedmáková et al. 2019). Similarly, decline of Abies alba in changing environmental conditions was documented by Mrkva (1994) and Mikulenka et al. (2020).

The frequently reported impact of red deer on vegetation - in many localities causing severe browsing and bark stripping damage to regeneration (Corney et al. 2008; Rogers et al. 2008; Hédl et al. 2010; Vacek et al. 2015b; Cukor et al. 2019), was not confirmed in our study.

\subsection{Diversity of herb layer}

In the herb layer the relative level of species richness has increased on all plots except PRP 5. The species heterogeneity on PRP 2-4 has increased moderately, while it decreased slightly to moderately only on PRP 1 and 5. It was proved at the Kozínek SAC that the higher species richness of herb layer is usually characteristic of forest stands with higher tree species diversity. Similar conclusions were drawn by Vockenhuber et al. (2011). Some studies reported positive relations between the diversity of tree layer and herb layer (Ingerpuu et al. 2003; Mölder et al. 2008), others did not find any significant relation (Borchsenius et al. 2004; Houle 2007). In the study of 
Mölder et al. (2014) a positive relationship between the biodiversity of tree layer and herb layer was demonstrated in the Hainich National Park. In general, compared to coniferous forests higher biodiversity was observed in broadleaved forests (Berger \& Puettman 2000; Hart \& Chen 2008).

Currently, the herb layer on the studied plots (except PRP 5) is more shaded and trophic than in 1961 thanks to more abundant natural generative regeneration. On PRP 1-5 the number of species in the herb layer increased by $15-64 \%$ while on PRP 5 it decreased by $2 \%$. This increase is caused mainly by a high number of seedlings of different tree species. But the total number of species in all relevés on PRP 1-5 has not basically changed. In similar studies a moderate increase in the number of species in a relevé is reported (Thimonier et al. 1994; Wild et al. 2004; Van Calster et al. 2007; Šamonil \& Vrška 2008), but mostly a moderate to pronounced decrease was observed (Hédl 2004; Rogers et al. 2008; Naaf \& Wulf 2010; Kopecký et al. 2013). There are also studies showing that the number of species did not change in time (Taverna et al. 2005; Keith et al. 2009), which is consistent also with our results.

Scree forests were richer in species number than herb-rich beech forests in the studied locality. However, they were highly variable proportionally to their developmental stage. In scree forests the number of species in the herb layer was a reaction mainly to light quantity when the species diversity was decreasing with increasing overshadowing. In herb-rich beech forests the effect of lower light intensities did not have any influence, but the effect of a change in moisture played its role.

Declining species were mainly light-demanding ones (e.g. Veronica chamaedrys agg.). On the contrary, among the newly appearing ones there were shade-tolerant species (e.g. Athyrium filix-femina, Geum urbanum, Viola reichenbachiana). The majority of the above-mentioned newly appearing species are also plants requiring higher soil moisture. Among the newly appearing species, increased the representation of the species of nutrientrich sites (e.g. Gallium odoratum) (Hofmeister et al. 2004). As a result of natural regeneration graminoids were also declining (mainly Melica nutans and Poa nemoralis). In relation to global warming, increase occurrence of Hepatica nobilis and Isopyrum thalictroides and decrease of Actaea spicata and Campanula trachelium was observed in study area.

In the forest vegetation due to an increase in the canopy closure (frequently caused by advanced natural regeneration) species were prospering that were adapted to overshadowing and specific conditions given by the leaf shedding of broadleaved species (e.g. Hepatica nobilis). The adaptation to restricted light access consists in a shift of phenological phases to earlier spring when the trees do not have any leaves yet, which allows the plants to receive sufficient solar radiation even in conditions of overshadowing (Dahlgren et al. 2006; Kopecký et al.
2013). An increase in the number of spring species was recorded by Brewer (1980) but von Oheim \& Brunet (2007) reported a decrease.

Average Ellenberg's indicator values did not confirm any change in the moisture characteristics but other studies showed that the restriction of light and radiation into a forest stand decreases evapotranspiration from the undergrowth and the environment becomes more humid (Decocq et al. 2005; Hédl et al. 2010); on the contrary, moisture is decreasing with opening canopy (Hédl 2004).

There was no difference in EIV for the soil reaction, thus we conclude that the influence of acidification has not been evident in the area of Kozínek SAC in the last 55 years. Since the soil reaction has a crucial influence on diversity (Brunet et al. 1997; Hofmeister et al. 2009; Vacek et al. 2017a), an increase in soil acidity is considered as important factors changing the type of forest vegetation (Falkengren-Grerup 1995). The calcareous marlstone bedrock probably plays its role (Mikeska et al. 2000), acting as a buffer against acidification (Thimonier et al. 1994). However, in other areas changes caused by soil acidification were recorded (Hédl 2004; Van Calster et al. 2007). Important factors are atmospheric depositions of compounds, and forest succession and nitrogen accumulation in the environment that contributes to soil acidification (De Schrijver et al. 2006; Hůnová et al. 2017).

\subsection{Effect of forest management}

It is to state that studied forest stands which were managed by small-scale systems, in the past mainly by coppicing, and later by shelterwood and selection felling, have maintained high species biodiversity during the years of observation. Significantly higher biodiversity was observed in scree forests in comparison with herbrich beech forests. Based on a comparison of PRP 5 (forest with prevailing coppice shoots in the tree layer) and PRP 3 (forest of generative origin) it is to conclude that at sites of scree forests coppice maintain higher biodiversity than high forests. Such a comparison is not available for herb-rich beech forests because they have always been regenerated generatively.

Similar results from forests where coppicing was abandoned were described by Corney et al. (2008), Rogers et al. (2008), Verheyen et al. (2012). Our results confirm the conclusions about vegetation changes presented by Mölder et al. (2008). Comparing different functional groups of forests Vockenhuber et al. (2011) found that higher tree diversity is consistent with an increased number of flowering herbs. It may be caused by plant functional groups that have different requirements for sources and therefore they have different reactions to gradients of ecological conditions (Tinya et al. 2009). Trees species often influence the herb layer by a change in the availability of resources and ecological conditions in the lower forest storeys (Barbier et al. 2008). It is especially 
the influence of light availability for the herb layer, which is a result of different light transmittance through the tree crowns, or the influence on the soil structure and its acidity through litterfall and its decomposability (Mölder et al. 2014).

Our study provided results that are many times consistent with similar published researches from other areas in the Czech Republic and in other countries (Hédl 2004; Van Calster et al. 2007; Rogers et al. 2008; Rooney 2008; Baeten et al. 2009; Keith et al. 2009; Bunn et al. 2010; Hédl et al. 2010; Verheyen et al. 2012; Kopecký et al. 2013). At the Kozínek SAC it is mainly a gradual change in forest management, i.e. conversion of coppice forest to high forest that modified the forest environment. This assumption is consistent with Durak (2012), who considered the forest management method as one of the most important factors influencing forest site and stand conditions.

\section{Conclusion}

The studied nature protected area Kozínek of the Natura 2000 belongs to the most valuable remnants of natural mixed beech forests in the Czech Republic. Biodiversity of scree forests in the past managed as a coppice or coppice with standards was greater than in herb-rich beech forests in both observation periods. There are several potential causes of changes in the biodiversity of scree forests and herb-rich beech forests at Kozínek SAC. The main cause is a change in forest management from coppice forest to high forest while small-scale management methods have been maintained. Climate change has also influenced the species diversity dynamics, but on a smaller scale compared to silviculture practises. In this connection, increase in the population of thermophilic plants was documented. During the 55 years, canopy of tree layer increased and thus a decrease was observed in light-demanding species of herb layer, while population of shade tolerant herb species and seedlings of trees increased. An important role played considerable expansion of natural regeneration. Eutrophisation was also an important factor, especially due to nitrogen deposition. As a result, new species of nitrophilous herbs appeared. The most substantial changes occurred in species richness, especially in its increase in the tree layer. However, limited number of research plots and slight differences of used methods in both periods in this case study must be considered when interpreting the present results.

\section{Acknowledgement}

This study was supported by the Czech University of Life Sciences Prague, Faculty of Forestry and Wood Sciences, Internal Grant Agency, ProjectNo.A_20_03. We are grateful to two anonymous reviewers and editor for their constructive comments and valuable suggestions that helped to improve the manuscript.

\section{References}

Ammer, C., 1996: Impact of ungulates on structure and dynamics of natural regeneration of mixed mountain forests in the Bavarian Alps. Forest Ecology and Management, 88:43-53.

Arrieta, S., Suarez, F., 2005: Spatial patterns of seedling emergence and survival a critical phase in holly (Ilex aquifolium L.) woodland recruitment in Central Spain. Forest Ecology and Management, 205:267282.

Baeten, L., Bauwens, B., De Schrijver, A., De Keersmaeker, L., Van Calster, H., Vandekerkhove, K. et al., 2009: Herb layer changes (1954-2000) related to the conversion of coppice-with-standards forest and soil acidification. Applied Vegetation Science, 12:187-197.

Barbier, S., Gosselin, F., Balandier, P., 2008: Influence of tree species on understory vegetation diversity and mechanisms involved-a critical review for temperate and boreal forests. Forest Ecology and Management, 254:1-15.

Battles, J. J., Shlisky, A. J., Barrett, R. H., Heald, R. C., Allen-Diaz, B. H., 2001: The effects of forest management on plant species diversity in a Sierran conifer forest. Forest Ecology and Management, 146:211222.

Beckage, B., Lavine, M., Clark, J. S., 2005: Survival of tree seedling sacross space and time: estimates from long-term count data. Journal of Ecology, 93:11771184.

Bellemare, J., Motzkin, G., Foster, D. R., 2002: Legacies of the agricultural past in the forested present: anassessment of historical land-use effects on rich mesic forests. Journal of Biogeography, 29:14011420.

Berger, A. L., Puettmann, K. J., 2000: Overstory composition and stand structure influence herbaceous plant diversity in the mixed aspen forest of northern Minnesota. The American Midland Naturalist, 143:111-125.

Borchsenius, F., Nielsen, P. K., Lawesson, J. E., 2004: Vegetation structure and diversity of an ancient temperate deciduous forest in SW Denmark. Plant Ecology, 175:121-135.

Bošela, M., Štefančík, I., Petráš, R., Vacek, S., 2016:The effects of climate warming on the growth of European beech forests depend critically on thinning strategy and site productivity. Agricultural and Forest Meteorology, 222:21-31.

Brewer, R., 1980: A half-century of changes in the herb layer of a climax deciduous forest in Michigan. Journal of Ecology, 68:823-832.

Brunet, J., 2007: Plant colonization in heterogeneous landscapes: an 80-year perspective on restoration of broadleaved forest vegetation. Journal of Applied Ecology, 44:563-572. 
Bulušek, D., Vacek, Z., Vacek, S., Král, J., Bílek, L., Králíček, I., 2016: Spatial pattern of relict beech (Fagus sylvatica L.) forests in the Sudetes of the Czech Republic and Poland. Journal of Forest Science, 62:293-305.

Bunn, W. A., Jenkins, M. A., Brown, C. B., Sanders, N.J. et al., 2010: Change within and among forest communities: the influence of historic disturbance, environmental gradients, and community attributes. Ecography, 33:425-434.

Carvalho, J. P. F., 2011: Composition and structure of natural mixed-oak stands in northernand central Portugal. Forest Ecology and Management, 262:19281937.

Ciancio, O., Corona, P., Lamonaca, A., Portoghesi, L., Travaglini, D., 2006: Conversion of clearcut beech coppices into high forests with continuous cover: A case study in central Italy. Forest Ecology and Management, 224:235-240.

Clark, P. J., Evans, F. C., 1954: Distance to nearest neighbour as a measure of spatial relationship in populations. Ecology, 35:445-453.

Corney, P. M., Kirby, K. J., Le Duc, M. G., Smart, S. M., McAllister, H. A., Marrs, R. H., 2008: Changes in the field-layer of Wytham Woods - assessment of the impacts of a range of environmental factors controlling change. Journal of Vegetation Science, 19:287-298.

Crow, T. R., Buckley, D. S., Nauertz, E. A., Zasada, J. C., 2002: Effects of management on the composition and structure of northern hardwood forests in Upper Michigan. Science, 48:129-145.

Cukor, J., Vacek, Z., Linda, R., Vacek, S., Marada, P., Šimůnek, V., Havránek, F., 2019: Effects of bark stripping on timber production and structure of Norway spruce forests in relation to climatic factors. Forests, 10:320.

Čermák, P., Mikita, T., Trnka, M., Štěpánek, P., Jurečka, F., Kusbach, A., Šebesta, J., 2018: Changes of Climate Characteristics of Forest Altitudinal Zones within the Czech Republic and their Possible Consequences for Forest Species Composition. Baltic Forestry, 24:234248.

Dahlgren, J. P., Eriksson, O., Bolmgren, K., Strindell, M., Ehrlen, J., 2006: Specific leaf area as a superior predictor of changes in field layer abundance during forest succession. Journal of Vegetation Science, 17:577-582.

David, F. N., Moore, P. G., 1954: Notes on contagious distributions in plant populations. Annals of Botany of London, 18:47-53.

Decocq, G., Aubert, M., Dupont, F., Bardat, J., WattezFranger, A., Saguez, R. et al., 2005: Silviculturedriven vegetation change in a European temperate deciduous forest. Annals of Forest Science, 62:313323.
Dulamsuren, C., Hauck, M., Kopp, G., Ruff, M., Leuschner, C., 2017: European beech responds to climate change with growth decline at lower, and growth increase at higher elevations in the center of its distribution range (SW Germany). Trees, 31:673-686.

Dentener, F., Stevenson, D., Ellingsen, K., Van Noije, T., Scultz, M.,Amann, M. et al., 2006: The global atmospheric environment for the next generation. Environmental Science and Technology, 40:3586-3594.

De Schrijver, A., Mertens, J., Geudens, G., Staelens, J., Campforts, E., Luyssaert, S. et al., 2006: Acidification of forested podzols in North Belgium during the period 1950-2000. The Science of the Total Environment, 361:189-95.

Durak, T., 2012: Changes in diversity of the mountain beech forest herb layer as a fiction of the forest management method. Forest Ecology and Management, 276:154-164.

Dzwonko, Z., Gawroński, S., 2002: Effect of litter removal on species richness and acidification of a mixed oak-pine woodland. Biological Conservation, 106:389-398.

Ellenberg, H., Weber, H. E., Düll, R., Wirth, V., Werner, W., Paulißen, D., 1992: Zeigerwerte von Pflanzen in Mitteleuropa. Scripta Geobotanica, 18:1-248.

Emborg, J., Christensen, M., Heilmann-Clausen, J., 2000: The structural dynamics of Suserup Skov, a near-natural temperate deciduous forest in Denmark. Forest Ecology and Management, 126:173-189.

Fabrika, M., Ďurský, J., 2005: Algorithms and software solution of thinning models for SIBYLA growth simulator. Journal of Forest Science, 51:431-445.

Falk, W., Hempelmann, N., 2013: Species favourability shift in europe due to climate change: a case study for Fagus sylvatica L. and Picea abies (L.) Karst. based on an ensemble of climate models. Journal of Climatology.

Falkengren-Grerup, U., 1995: Long-term changes in flora and vegetation in deciduous forests of southern Sweden. Ecological Bulletins, 44:215-226.

Faltysová, H., Mackovčín, P., Sedláček, P. et al., 2002: Chráněná území ČR, svazek V. Královéhradecko. Agentura ochrany př́rody a krajiny ČR a EkoCentrum Brno, Praha.

Füldner, K., 1995: Strukturbeschreibung in Mischbeständen. Forstarchiv, 66:235-606.

Hart, S. A., Chen, H. Y. H., 2008: Fire, logging, and overstory affect understory abundance, diversity, and composition in boreal forest. Ecological Monographs, 78:123-140.

Hédl, R., 2004: Vegetation of beech forests in the Rychlebské Mountains, Czech Republic, re-inspected after 60 years with assessment of environmental changes. Plant Ecology 170: 243-265. 
Hédl, R., Kopecký, M., Komárek, J., 2010: Half a century of succession in a temperate oakwood: from speciesrich community to mesic forest. Diversity and Distributions, 16:267-276.

Hédl, R., Bernhardt-Römermann, M., Grytnes, J. A., Jurasinski, G., Ewald, J., 2017: Resurvey of historical vegetation plots: a tool for understanding long-term dynamics of plant communities. Applied Vegetation Science, 20:161-163.

Heinrichs, S., Schmidt, W., 2017: Biotic homogenization of herb layer composition between two contrasting beech forest communities on limestone over 50 years. Applied Vegetation Science, 20: 271-281.

Hermy, M., Verheyen, K., 2007: Legacies of the past in the present-day forest biodiversity: a review of past land-use effects on forest plant species composition and diversity. Ecological Research, 22:361-371.

Hill, M. O., 1973: Diversity and evencess: a unifying notation and is consequenses. Ecology, 54:427-432.

Hisano, M., Searle, E. B., Chen, H. Y., 2018: Biodiversity as a solution to mitigate climate change impacts on the functioning of forest ecosystems. Biological Reviews, 93:439-456.

Hofmeister, J., Mihaljevič, M., Hošek, J., 2004: The spread of ash (Fraxinus excelsior) in some European oak forests: an effect of nitrogen deposition or successional change? Forest Ecology and Management, 203:35-47.

Hofmeister, J., Hošek, J., Modrý, M., Roleček, J., 2009: The influence of light and nutrient availability on herb layer species richness in oak-dominated forests in central Bohemia. Plant Ecology, 205:57-75.

Houle, G., 2007: Determinants of fine-scale plant species richness in a deciduous forest of northeastern North America. Journal of Vegetation Science, 18:345-354.

Chapman, J. I., McEwan, R. W., 2013: Spatiotemporal dynamics of- $\alpha$ - and $\beta$-diversity across topographic gradients in the herbaceous layer of an old-growth deciduous forest. Oikos, 122:1679-1686.

Chapman, R. A., Heitzman, E., Shelton, M. G., 2006: Long-term changes in forest structure and species composition of anupland oak forest in Arkansas. Forest Ecology and Management, 236:85-92.

Ingerpuu, N., Vellak, K., Liira, J., Partel, M., 2003: Relationships between species richness patterns in deciduous forests at the north Estonian limestone escarpment. Journal of Vegetation Science, 14:773-780.

Iverson, L. R., Prasad, A. M., 2001: Potential changes in tree species richness and forest community types following climate change. Ecosystems, 4:186-199.

Jaehne, S. C., Dohrenbusch, A., 1997: Ein Verfahren zur Beurteilung der Bestandesdiversität. Forstwissenschaftliches Centralblatt, 116:333-345.

Keith, S. A., Newton, A. C., Morecroft, M. D., Bealey, C. E., Bullock, J. M., 2009: Taxonomic homogenization of woodland plant communities over 70 years. Proceedings of the Royal Society. Biological Sciences, 276: 3539-3544.
Kneeshaw, D. D., Prévost, M., 2007: Natural canopy gap disturbances and their role in maintaining mixed species forests of central Quebec. Canadian Journal of Forest Research, 37: 1534-1544.

Kopecký, M., Hédl, R., Szabó, P., 2013: Non-random extinctions dominate plant community changes in abandoned coppices. Journal of Applied Ecology, 50:79-87.

Král, J., Vacek, S., Vacek, Z., Putalová, T., Bulušek, D., Štefančík, I., 2015: Structure, development and health status of spruce forests affected by air pollution in the western Krkonoše Mts. in 1979-2014. Forestry Journal, 61:175-187.

Králíček, I., Vacek, Z., Vacek, S., Remeš, J., Bulušek, D., Král, J. et al., 2017: Dynamics and structure of mountain autochthonous spruce-beech forests: impact of hilltop phenomenon, air pollutants and climate. Dendrobiology, 77:119-137.

Kramer, K., Degen, B., Buschbom, J., Hickler, T., Thuiller, W., Sykes, M. T., de Winter, W., 2010: Modelling exploration of the future of European beech (Fagus sylvatica L.) under climate change-range, abundance, genetic diversity and adaptive response. Forest Ecology and Management, 259:2213-2222.

Kunstler, G., Curt, T., Bouchaud, M., Lepart, J., 2005: Growth, mortality, and morphological response of European beech and downy oak along alight gradient in sub-Mediterranean forest. Canadian Journal of Forest Research, 35:1657-1668.

Lhotka, J. M., 2013: Effect of gap size on mid-rotation stand structure and species composition in a naturely regenerated mixed broadleaf forest. New Forests, 44:311-325.

Lindenmayer, D. B., Margules, C. R., Botkin, D. B., 2000: Indicators of biodiversity for ecological sustainable forest management. Conservation Biology, 14:941-950.

Lucas-Borja, M. E., Fonseca, T. F., Lousada, J. L., SilvaSantos, P., Garcia, E. M., Abellán, M.A., 2012: Natural regeneration of Spanish black pine [Pinus nigra Arn. ssp. salzmannii (Dunal) Franco] at contrasting altitudes in a Mediterranean mountain area. Ecological Research, 27:913-921.

Machar, I., Vozenilek, V., Simon, J., Pechanec, V., Brus, J., Fulneček, P., Vitek, T., 2017: Joining of the historical research and future prediction as a support tool for the assessment of management strategy for European beech-dominated forests in protected areas. Nature Conservation, 22:51-78.

Margalef, R., 1958: Information theory in ecology. General Systematics, 3:36-71.

Mattila, M., Kjellander, P., 2017:The tree species matrix, influence on the level of herbivore browsing in mixed forest stands in southwest Sweden. Scandinavian Journal of Forest Research, 32:1-5. 
Matuszkiewicz, J. M., Kowalska, A., Kozłowska, A., Roo-Zielińska, E., Solon, J., 2013: Differences in plant-species composition, richness and community structure in ancient and post-agricultural pine forests in central Poland. Forest Ecology and Management, 310:567-576.

Meier, M., Stöhr, D., Walde, J., Tasser, E., 2017: Influence of ungulates on the vegetation composition and diversity of mixed deciduous and coniferous mountain forest in Austria. European Journal of Wildlife Research, 63:29.

Menhinick, C. F., 1964: A comparison of some speciesindividuals diversity indices appplied to samples of field insects. Ecology, 45:859-861.

Mikeska, M. et al., 2000: Oblastní plán rozvoje lesů PLO 24 - Sudetské mezihoří. ÚHÚL Brandýs nad Labem, Hradec Králové.

Mikulenka, P., Prokůpková, A., Vacek, Z., Vacek, S., Bulušek, D., Simon, J. et al., 2020: Effect of climate and air pollution on radial growth of mixed forests: Abies alba (Mill.) vs. Picea abies (L.) Karst. Central European Forestry Journal, 66:23-36.

Mölder, A., Bernhardt-Römermann, M., Schmidt, W., 2008: Herb-layer diversity in deciduous forests: raised by tree richness or beaten by beech? Forest Ecology and Management, 256:272-281.

Mölder, A., Streit, M., Schmidt, W., 2014: When beech strikes back: How strict nature conservation reduces herb-layer diversity and productivity in Central European deciduous forests. Forest Ecology and Management, 319:51-61.

Motta, R., 2003: Ungulate impact on rowan (Sorbus aucuparia L.) and Norway spruce (Picea abies (L.) Karst.) height structure in mountain forests in the eastern Italian Alps. Forest Ecology and Management, 181:139-150.

Mountford, M. D., 1961: On E. C. Pielou's index of nonrandomness. Journal of Ecology, 49:271-275.

Mrkva, R., 1994: Korovnice kavkazska (Dreyfusia nordmannianae Eckstein), obrana proti ní a její podíl na ústupu jedle. Lesnictvi - Forestry, 40:361-370.

Naaf, T., Wulf, M., 2010: Habitat specialists and generalists drive homogenization and differentiation of temperate forest plant communities at the regional scale. Biological Conservation, 143:848-855.

Paal, J., Turb, M., Köster, T., Rajandu, E., Liira, J., 2011: Forest land-use history affects the species composition and soil properties of old-aged hillock forests in Estonia. Journal of Forest Research, 16:244-252.

Packer, A., Clay, K., 2003: Soil pathogens and Prunus serotina seedling and sapling growth near conspecific trees. Ecology, 84:108-119.

Paquette, A., Vayreda, J., Coll, L., Messier, C., Retana, J., 2018: Climate change could negate positive tree diversity effects on forest productivity: a study across five climate types in Spain and Canada. Ecosystems, 21:960-970.
Paluch, J. G., 2007: The spatial pattern of a natural European beech (Fagus sylvatica L.) - silver fir (Abies alba Mill.) forest: A patch-mosaic perspective. Forest Ecology and Management, 253:161-170.

Paluch, J. G., Jastrzębski, R., 2013: Natural regeneration of shade-tolerant Abies alba Mill. in gradients of stand species compositions: Limitation by seed availability or safe microsites? Forest Ecology and Management, 307:322-332.

Paluch, J.G., Stępniewska, H., 2012: Effect of microsites on the survival, density, and ectomycorrhizal status of shade-tolerant Abies alba regeneration attacked by fungal pathogens. Canadian Journal of Forest Research, 42:720-732.

Petráš, R., Pajtík, J., 1991: Sústava česko-slovenských objemových tabuliek drevín. Lesnícky časopis - Forestry Journal, 37:49-56.

Petritan, A. M., Biris, I. A., Merce, O., Turcu, D. O., Petritan, I. C., 2012: Structure and diversity of a natural temperate sessile oak (Quercus petraea L.) - European Beech (Fagus sylvatica L.) forest. Forest Ecology and Management, 280:140-149.

Pielou, E. C., 1959: The use of point-to-plant distances in the study of the pattern of plant populations. Journal of Ecology, 47:607-613.

Pielou, E. C., 1975: Ecological diversity. $1^{\text {st }}$ Ed. Wiley, New York.

Piovesan, G., Di Filippo, A., Alessandrini, A., Biondi, F., Schirone, B., 2005: Structure, dynamics and dendroecology of an old-growth Fagus forest in the Apeninnes. Journal of Vegetation Science, 16:13-28.

Piussi, P., Farrell, P., 2000: Interaction between society and forest ecosystems: challenges for the near future. Forest Ecology and Management, 132:21-28.

Poleno, Z., Vacek, S. et al., 2011: Pěstování lesů I. Ekologické základy pěstování lesů. Lesnická práce, Kostelec nad Černými lesy.

Pretzsch, H., 2006: Wissen nutzbar machen für das Management von Waldökosystemen. Allgemeine Forstzeitschrift/Der Wald, 61:1158-1159.

Quitt, E., 1971: Klimatické oblasti Československa. Academia, Studia Geographica 16, Brno.

Rackham, O., 2008: Ancient woodlands: modern threats. New Phytologist, 180:571-86.

Remeš, J., Bílek, L., Novák, J., Vacek, Z., Vacek, S., Putalová, T., Koubek, L., 2015: Diameter increment of beech in relation to social position of trees, climate characteristics and thinning intensity. Journal of Forest Science, 61:456-464.

Reineke, L. H., 1933: Perfecting a stand density index for even-aged forests. Journal Agricultural Research, 46:627-638.

Rogers, D. A., Rooney, T. P., Olson, D., Waller, D. M., 2008: Shifts in southern Wisconsin forest canopy and understory richness, composition, and heterogeneity. Ecology, 89:2482-2492. 
Rooney, T.P., 2008: Comparison of co-occurrence structure of temperate forest herb-layer communities in 1949 and 2000. Acta Oecologica, 34:354-360.

Sedmáková, D., Sedmák, R., Bosela, M., Ježík, M., Blaženec, M., Hlásny, T., Marušák, R., 2019: Growthclimate responses indicate shifts in the competitive ability of European beech and Norway spruce under recent climate warming in East-Central Europe. Dendrochronologia, 54:37-48.

Serra-Diaz, M. J., Ninyerol, M., Lloret, F., 2012: Coexistence of Abies alba (Mill.) - Fagus sylvatica (L.) and chmate chase impact in the Iberian Peninsula:climatic-niche perspective approach. Flora, 207:10-18.

Shannon, C. E., 1948: A mathematical theory of communications. The Bell System Technical Journal, 27:379-423.

Silvertown, J., 2004: Plant coexistence and the niche. Trends in Ecology and Evolution, 19: 605-611.

Simpson, H., 1949: Measurement of diversity. Nature, 163:688.

Sitzia, T., Trentanovi, G., Dainese, M., Gobbo, G., Lingua, E., Sommacal, M., 2012: Stand structure and plant species diversity in managed and abandoned silver fir mature wood lands. Forest Ecology and Management, 270:232-238.

Snyder, R. E., Chesson, P., 2004: How the spatial scales of dispersal, competition, and environmental heterogenity interact to affect co-existence. American Naturalist, 164:633-650.

Spiecker, H., 2003: Silvicultural management in maintaining biodiversity and resistance of forests in Europe-temperate zone. Journal of Environmental Management, 67:55-65.

Strandberg, B., Kristiansen, S. M., Tybirk, K., 2005: Dynamic oak-scrub to forest succession: effects of management on understorey vegetation, humus forms and soils. Forest Ecology and Management, 211:318-328.

Szwagrzyk, J., Czerwczak, M., 1993: Spatial patterns of trees in natural forests of East-Central Europe. Journal of Vegetation Science, 4:469-476.

Szwagrzyk, J., Szewczyk, J., Bodziarczyk, J., 1997: Spatial variability of a natural stand in the Babia Góra National Park. Folia Forestalia Polonica, Series A, 39:61-78.

Szwagrzyk, J., Szewczyk, J., Maciejewski, Z., 2012: Shade-tolerant tree species from temperate forests differ in thein competitive abilities: a case study from Roztocze, south-eastern Poland. Forest Ecology and Management, 282:28-35.

Šamonil, P., Vrška, T., 2008: Long term vegetation dynamics in the Šumava Mts. Natural spruce-firbeech forests. Plant Ecology, 196:197-214.
Šimůnek, V., Vacek, Z., Vacek, S., Králíček, I., Vančura, K., 2019: Growth variability of European beech (Fagus sylvatica L.) natural forests: Dendroclimatic study from Krkonoše National Park. Central European Forestry Journal, 65:92-102.

Taverna, K., Peet, R. K. and Phillps, L. C., 2005: Longterm change in ground-layer vegetation of deciduous forests of the North Carolina Piedmont, USA. Journal of Ecology, 93: 202-213.

Thimonier, A., Dupouey, J. L., Bost, F., Becker, M., 1994: Simultaneous eutrophication and acidification of a forest in North-East France. New Phytologist, 126:533-539.

Tinya, F., Márialigeti, S., Király, I., Németh, B., Ódor, P., 2009: The effect of light conditions on herbs, bryophytes and seedlings of temperate mixed forests in Örség, Western Hungary. Plant Ecology, 204:69-81.

Tolasz, R., Míková, T., Valeriánová, T., Voženílek, V., 2007: Climate atlas of Czechia. Czech Hydrometeorological Institute and Palacký University, Olomouc.

Vacek, S., Vacek, Z., Podrazský, V., Bílek, L., Bulušek, D., Štefančík, I. et al., 2014a: Structural Diversity of Autochthonous Beech Forests in Broumovské Stěny National Nature Reserve, Czech Republic. Austrian Journal of Forest Science, 131:191-214.

Vacek, S., Vacek, Z., Bulušek, D., Bílek, L., Schwarz, O., Simon, J., Štícha, V., 2015b: The role of shelterwood cutting and protection against game browsing for the regeneration of silver fir. Austrian Journal of Forest Science, 132:81-102.

Vacek, S., Černý, T., Vacek, Z., Podrázský, V., Mikeska, M., Králíček, K., 2017a: Long-term changes in vegetation and site conditions in beech and spruce forests of lower mountain ranges of Central Europe. Forest Ecology and Management, 398:75-90.

Vacek, S., Vacek, Z., Ulbrichová, I., Bulušek, D., Prokůpková, A., Král, J., Vančura, K., 2019b: Biodiversity dynamics of differently managed lowland forests left to spontaneous development in Central Europe. Austrian Journal of Forest Science, 136:249282.

Vacek, Z., Vacek, S., Bílek, L., Král, J., Remeš, J., Bulušek, D., Králíček, I., 2014b: Ungulate Impact on Natural Regeneration in Spruce-Beech-Fir Stands in Černý důl Nature Reserve in the Orlické Hory Mountains, Case Study from Central Sudetes. Forests 5: 2929-2946.

Vacek, Z., Vacek, S., Podrazský, V., Bílek, L., Štefančík, I., Moser, W. K. et al., 2015a: Effect of tree layer and microsite on the variability of natural regeneration in autochthonous beech forests. Polish Journal of Ecology, 63:233-246.

Vacek, Z., Vacek, S., Bílek, L., Remeš, J., Štefančík, I., 2015c: Changes in horizontal structure of natural beech forests on an altitudinal gradient in the Sudetes. Dendrobiology, 73:33-45. 
Vacek, Z., Bulušek, D., Vacek, S., Hejcmanová, P., Remeš, J., Bílek, L., Štefančík, I., 2017b: Effect of microrelief and vegetation cover on natural regeneration in European beech forests in Krkonoše national parks (Czech Republic, Poland). Austrian Journal of Forest Science, 134:75-96.

Vacek, Z., Vacek, S., Slanař, J., Bílek, L., Bulušek, D., Štefančík, I. et al., 2019a: Adaption of Norway spruce and European beech forests under climate change: from resistance to close-to-nature silviculture. Central European Forestry Journal, 65:129-144.

Van Calster, H., Baeten, L., Schrijver, A. D., Keersmaeker, L. D., Rogister, J. E., Verheyen, K., Hermy, M., 2007: Management driven changes (1967-2005) in soil acidity and the understorey plant community following conversion of a coppice-with-standards forest. Forest Ecology and Management, 241:258-271.

Vejlupek, M., 1986: Strukturní stavba polické a svatoňovicko-hronovské pánve. Věstník Ústředního ústavu geologického, 61:139-148.

Vejlupek, M., 1990: Geologická mapa ČR, 1: 50 000, list 04-33. Náchod, Ústřední ústav geologický.

Vera, F. W. M., 2000: Grazing ecology and forest history. CABI Publishing, Oxon.

Verheyen, K., Baeten, L., Frenne, P.D., Bernhardt-Roemermann, M., Brunet, J., Cornelis, J. et al., 2012: Driving factors behind the eutrophication signal in understorey plant communities of deciduous temperate forests. Journal of Ecology, 100:352-365.

Vesecký, A., Briedoň, V., Karský, V., Petrovič, Š., 1961: Podnebí Československé socialistické republiky tabulky. Praha, Hydrometeorologický ústav.

Vockenhuber, E. A., Scherber, C., Langenbruch, C., Meißnerc, M., Seidel, D., Tscharntke, T., 2011: Tree diversity and environmental context predict herb species richness and cover in Germany's largest connected deciduous forest. Perspectives in Plant Ecology, Evolution and Systematics, 13:111-119. von Oheimb, G., Westphal, Ch., Härdtle, W., 2007: Diversity and spatiotemporal dynamics of dead wood in a temperate near-natural beech forest (Fagus sylvatica). European Journal of Forest Research, 126:359-370.

von Oheimb, G., Brunet, J., 2007: Dalby Söderskog revisited: long-term vegetation changes in a south Swedish deciduous forest. Acta Oecologica, 31:229-242.

Ward, J. S., Parker, G. R., Ferrandino, F. J., 1996: Longterm spatial dynamics in an old-growth decidous forest. Forest Ecology and Management, 83:189-202.

Wild, J., Neuhauslová, Z., Sofron, J., 2004: Changes of plant species composition in the Šumava spruce forests, SW Bohemia, since the 1970s. Forest Ecology and Management, 187:117-132.

Wilson, J. B., 2011: The twelve the ories of co-existence in plant communities: the doubtful, the important and the unexplored. Journal of Vegetation Science, 22:184-195.

Wulf, M., 2003: Preference of plant species for woodlands with different habitat continuities. Flora, 198:444-460.

Zlatník, A., 1978: Lesnická fytocenologie. SZN, Praha.

Other sources

AOPK, 2004: Evropsky významné lokality ČR. CZ0520507 - Kozínek, Praha, AOPK ČR.

R Core Team, 2018: R: A language and environment for statistical computing. R Foundation for Statistical Computing, Vienna, Austria. Available on https:// www.R-project.org/. 